Polonia Sacra 18 (2014) nr 3 (36) · s. 77-93

ks. Antoni Nadbrzeżny ${ }^{1}$

Katolicki Uniwersytet Lubelski Jana Pawła II

\title{
Pastoralne implikacje encykliki Jana Pawła II Sollicitudo rei socialis
}

Kanonizacja Jana Pawła II stanowi znakomitą okazję do ponownej lektury społecznej myśli papieża w kontekście dokonujących się dziś zmian politycznych i kulturowych. Nauczanie Jana Pawła II, naznaczone ogromną wrażliwością antropologiczną, bez wątpienia mieści się w nurcie personalizmu komunitarnego, harmonijnie łączącego troskę o pełny rozwój zarówno indywidualnej osoby ludzkiej, jak i całych narodów ${ }^{2}$. Poczucie głębokiej odpowiedzialności ojca świętego za losy świata znajdującego się w sieci rozmaitych skomplikowanych powiązań ekonomicznych, społecznych i politycznych przemawia do sumienia czytelnika papieskiej encykliki Sollicitudo rei socialis, stanowiąc zachętę do odważnego zaangażowania w dzieło budowania pokoju na drodze solidarnego rozwoju ludzi i narodów.

Krytykowany przez Jana Pawła II podział świata na dwa wrogie bloki polityczno-militarne (komunistyczny Wschód i kapitalistyczny Zachód) do niedawna wydawał się należeć do bezpowrotnej przeszłości, jednak ostatnie wydarzenia związane z aneksją Krymu przez Rosję oraz eskalacją konfliktu między Rosją i Ukrainą budzą uzasadniony lęk przed powrotem zjawiska „zimnej wojny” grożącej z czasem wybuchem otwartego konfliktu zbrojne-

$1 \quad$ Ks. dr hab. Antoni Nadbrzeżny - adiunkt przy Katedrze Pneumatologii i Eklezjologii w Instytucie Teologii Dogmatycznej Katolickiego Uniwersytetu Lubelskiego Jana Pawła II.

2 Na temat personalistycznego wymiaru filozofii i teologii Karola Wojtyły zob. R. Buttiglione, Myśl Karola Wojtyły, tłum. J. Merecki, Lublin 2010. 
go. Zasygnalizowane okoliczności skłaniają do rzetelnej analizy przesłania encykliki Sollicitudo rei socialis. W niniejszym artykule zostanie ukazana zarówno geneza, jak i specyfika papieskiego dokumentu, ponadto omówione zostaną trzy kluczowe wartości, jakimi są rozwój, solidarność i pokój. Praktycznym celem artykułu będzie sformułowanie konkretnych sugestii dla duszpasterstwa parafialnego, które pozostaje ważnym adresatem społecznego orędzia ojca świętego.

\section{Geneza i okoliczności powstania encykliki}

Druga encyklika społeczna Jana Pawła II, dotycząca aktualnych problemów rozwoju ludzi i narodów, nosi łaciński tytuł Sollicitudo rei socialis, który w polskim tłumaczeniu brzmi: „Troska o sprawy społeczne”. Papieski dokument wyraźnie wskazuje, że społeczna, gospodarcza i polityczna dziedzina życia ludzkiego stanowi istotny przedmiot troski Kościoła w ramach jego ewangelizacyjnej misji. Podkreśla, że celem katolickiej nauki społecznej nie jest wypracowanie jakiegoś optymalnego ustroju polityczno-gospodarczego. Nie jest ona ,trzecią drogą pomiędzy liberalnym kapitalizmem i marksistowskim kolektywizmem", lecz wynikiem pogłębionej refleksji nad złożoną rzeczywistością społeczną, dokonanej w świetle wiary i tradycji Kościoła. Podstawowym jej zadaniem jest wyjaśnienie tej rzeczywistości poprzez wykazanie jej zgodności lub niezgodności z ewangeliczną nauką o człowieku i jego powołaniu doczesnym i nadprzyrodzonym. Nie jest ona żadną ideologią, lecz należy do dziedziny teologii moralnej. Ma charakter normatywny, gdyż zmierza do ukierunkowania chrześcijańskiego postępowania (por. SRS 41). Wypowiedź ta ma doniosłe znaczenie dla określenia tożsamości, metodologii, celów i sposobu uprawiania katolickiej nauki społecznej ${ }^{3}$.

Sollicitudo rei socialis powstała z okazji przypadającej w roku 1987 dwudziestej rocznicy wydania encykliki Pawła VI Populorum progressio poświęconej kwestii rozwoju i pokoju4. Jan Paweł II w rozmowie z kardynałem Rogerem Etchegarayem, przewodniczącym Papieskiej Rady Iustitia et Pax, zapowie-

Por. C. Strzeszewski, Katolicka nauka społeczna, Lublin 1994, s. 336.

Por. S. Pyszka, Krótko o społecznej nauce Kościoła, Kraków 2003, s. 49-50. 
dział, że pragnie nie tylko upamiętnić historyczną encyklikę Populorum progressio, lecz także ukazać jeszcze bogatszą i bardziej zróżnicowaną koncepcję rozwoju. Opatrzona datą 30 grudnia 1987 roku, została jednak ogłoszona dopiero 19 lutego następnego roku, co sprowokowało liczne komentarze w środowiskach dziennikarzy ${ }^{5}$.

Dokument posiada swój kontekst historyczny i polityczny. Powstał w epoce, w której funkcjonował podział na dwa bloki: kapitalistyczny i socjalistyczny. Obok tego istniał Trzeci Świat obejmujący państwa afrykańskie, nowo wyzwolone, będące na drodze rozwoju. Ponadto w obrębie najbogatszych krajów wykrystalizował się obszar biedy, zwany Czwartym Światem. Podczas gdy w krajach Ameryki Łacińskiej rozwijały się radykalne nurty teologii wyzwolenia, Polska, boleśnie doświadczona skutkami stanu wojennego, czerpała siłę ze społecznego ruchu „Solidarność” i żyła nadzieją na możliwość zmian politycznych i ekonomicznych.

Dokument podpisany przez Jana Pawła II powstawał w skomplikowanym procesie redakcyjnym. Stanowi owoc licznych konsultacji papieża z Kurią Rzymską i episkopatami różnych krajów oraz szczegółowych dyskusji na temat dynamicznych przemian społecznych zachodzących we współczesnym świecie. Styl wypowiedzi i zastosowane w Sollicitudo rei socialis słownictwo wyraźnie różnią się od języka wcześniejszych encyklik Jana Pawła II. Dokument stanowi przemyślaną syntezę społecznego nauczania papieża. Zawiera fachową terminologię występującą w literaturze naukowej ${ }^{6}$. Jest przykładem harmonijnego połączenia problematyki społecznej z refleksją biblijną, teologiczną, filozoficzną i modlitewną. Układ encykliki jest tradycyjny, jej struktura pozostaje przejrzysta i logiczna. Oprócz wstępu i zakończenia zawiera ona pięć rozdziałów zatytułowanych kolejno: Nowość encykliki „Populorum progressio”, Panorama świata wspótczesnego, Prawdziwy rozwój

5 Przedstawiciele mediów wyrażali zdziwienie z powodu opóźnienia enuncjacji papieskiego dokumentu zapowiadanego na rok 1987. Zastanawiali się, dlaczego w ciągu kilku miesięcy wolnych od apostolskich pielgrzymek papież zwleka z ogłoszeniem encykliki. Rzecznik Watykanu w żartobliwy sposób odpowiadał, że „papież odbywa pielgrzymkę do Kurii”, czyniąc aluzję do częstych spotkań ojca świętego z pracownikami Papieskiej Rady Iustitia et Pax poświęconych rozmowom nad ostatecznym kształtem encykliki Sollicitudo rei socialis. Por. G. Weigel, Świadek nadziei. Biografia papieża Jana Pawła II, tłum. M. Tarnowska i in., Kraków 2009, s. 704-705.

6 Por. C. Strzeszewski, Katolicka nauka społeczna, dz. cyt., s. 339. 
ludzki, Odczytywanie aktualnych problemów w świetle teologii oraz Niektóre wskazania szczegółowe.

Uwzględniając zmiany, które w ciągu dwudziestu lat dokonały się w sferze stosunków społecznych i gospodarczych, papież przedstawia w encyklice chrześcijański pogląd na istotę rozwoju ludzkości. Dokonuje trafnej oceny społecznych, kulturalnych i politycznych problemów w świetle Ewangelii oraz formułuje cały szereg szczegółowych wskazań dla moralnej odnowy współczesnego świata ${ }^{7}$. Dokument jest wyjątkowy także pod względem zastosowanej w nim metody. Punktem wyjścia papieskich rozważań nie jest jakieś szczegółowe zagadnienie społeczne, które w miarę postępujących analiz stopniowo zyskiwałoby coraz pełniejsze wyjaśnienie, lecz globalna wizja społecznych problemów. Skłaniają one czytelnika do poszukiwania klucza służącego zaradzeniu największym bolączkom współczesnego człowieka ${ }^{8}$.

Myśl papieża ma charakter personalistyczny i historyczny. Konsekwentnie zmierza do ukazania osób ludzkich jako podmiotów odpowiedzialnych za budowanie ziemskiej społeczności i mających realny wpływ na dzieje świata (por. SRS 1). Ojciec święty dostrzega szczególne przyśpieszenie historii, które wyraża się w wielości i złożoności zjawisk prezentujących zmieniający się układ świata i jego nowe aspekty (por. SRS 4). Jest głęboko przekonany, że w okresie zwanym wigilią trzeciego milenium chrześcijaństwa świat dojrzał do przełomu i oczekuje na odważną reformę w dziedzinie myślenia i działania9.

\section{Wiodące idee}

Encyklika Sollicitudo rei socialis zasadniczo omawia dwie fundamentalne kwestie: dramatyczną sytuację świata pod koniec lat osiemdziesiątych ubiegłego wieku widzianą przez pryzmat krajów najuboższych oraz warun-

\footnotetext{
Por. C. Strzeszewski, Katolicka nauka społeczna, dz. cyt., s. 335.

8 Por. J. Majka, Nauka społeczna Kościoła, jej charakter i miejsce w orędziu ewangelicznym, [w:] Dokumenty nauki społecznej Kościoła, cz. 1, red. M. Radwan, L. Dyczewski, wyd. II zmienione, Lublin 1996, s. 53-54.
}

9 Por. J. Majka, Nauka społeczna Kościoła..., dz. cyt., s. 54. 
ki i wymogi prawdziwego rozwoju ${ }^{10}$. Spośród wielu interesujących kwestii poruszonych przez papieża warto bliżej zapoznać się z diagnozą współczesnego świata, integralną koncepcją rozwoju oraz relacją między solidarnością i pokojem.

\subsection{Problemy współczesnego świata}

Jan Paweł II dobrze zdawał sobie sprawę z faktu, że aktualny kontekst społeczny był diametralnie różny od sytuacji sprzed dwudziestu lat. Przede wszystkim głoszone w latach sześćdziesiątych XX wieku nadzieje na dynamiczny rozwój narodów nie spełniły się. Mimo godnych pochwały inicjatyw religijnych, humanitarnych i ekonomicznych, zmierzających do udzielenia pomocy nowym krajom powstałym w procesie dekolonizacji, ogólna ocena obecnej sytuacji z punktu widzenia rozwoju wypada zdecydowanie negatywnie. Papież zauważa, że w skali światowej zwiększył się dystans między bogatą Północą a biednym Południem. W konsekwencji pojawiły się znaczące podziały w ramach jednego globu na Pierwszy, Drugi, Trzeci i Czwarty Świat. Oznacza to w praktyce, że jedność świata została poważnie zagrożona (por. SRS 13).

Do społecznych i ekonomicznych wskaźników niedorozwoju należą: analfabetyzm, niezdolność obywateli do uczestnictwa w budowaniu społeczeństwa, liczne formy wyzysku, łamanie praw człowieka, dyskryminacja rasowa, ucisk społeczny, ekonomiczny, polityczny i religijny, niedostatek mieszkań, zjawisko bezrobocia lub niepełnego zatrudnienia oraz wzrastający wskaźnik zadłużenia krajów będących na drodze rozwoju. Papież zwraca uwagę na niepokojące zjawisko zanikania twórczej podmiotowości człowieka, wyrażające się w ograniczeniu prawa do inicjatywy gospodarczej w imię ideologicznych haseł „równości” wszystkich obywateli w społeczeństwie. Fatalnymi skutkami takiego działania są bierność społeczeństwa i zależność od biurokracji, które nieuchronnie prowadzą do wzrostu frustracji, skłonności do emigracji i spadku zaangażowania ludzi w życie narodu (por. SRS 15)11.

10 Por. J. Mazur, Katolicka nauka społeczna, Kraków 1992, s. 152.

11 Por. A. Klose, Katolicka nauka społeczna w zarysie, tłum. Z. Kowalska, Tarnów 1995, s. 35-36. 
Oprócz społecznych i ekonomicznych przyczyn hamujących rozwój trzeba dostrzec również czynniki polityczne. Jan Paweł II zwraca uwagę na istnienie dwóch przeciwstawnych bloków nazwanych umownie Wschodem i Zachodem, z których każdy dąży do asymilacji lub związania ze sobą grupy innych krajów. Przeciwstawność tych bloków w aspekcie politycznym ma swoje głębsze podstawy w różnicach ideologicznych. Podczas gdy Zachód czerpie swą inspirację z zasad liberalnego kapitalizmu, Wschód rozwija system oparty na marksistowskim kolektywizmie. Wspomniane bloki odwołują się do zupełnie odmiennych wizji człowieka, wolności i społeczeństwa. Proponują nie tylko różne formy organizacji pracy i struktury własności, ale dążą do rozwoju przeciwstawności militarnej. Prowadzi to do wzrostu napięcia między dwoma blokami, przybierającego charakter „zimnej wojny” oraz - poprzez wyścig zbrojeń - utrzymywania ludzi w poczuciu lęku przed otwartym i totalnym konfliktem (por. SRS 20).

Analizując funkcjonowanie dwóch przeciwstawnych bloków politycznych, papież podkreśla, że każdy z nich ma niedoskonałą koncepcję rozwoju i wymaga poważnych korekt. W sposób wyraźny stwierdza, że „nauka Kościoła jest krytyczna zarówno wobec kapitalizmu, jak i wobec kolektywizmu marksistowskiego" (SRS 21). Wypowiedź ta wywołała pewne błędne reakcje w kręgach dziennikarzy, którzy sugerowali, że papież na równi potępia marksizm i kapitalizm oraz niewystarczająco rozumie różnicę między NATO a Układem Warszawskim. Nie można przy tym zapomnieć, że encyklika ma wyraźny wydźwięk antytotalitarny i antykomunistyczny ${ }^{12}$. Ojciec święty zdecydowanie przeciwstawia się uzurpowaniu sobie przez jedną partię prawa do roli jedynego przewodnika i przestrzega, że taki system mimo głoszonych deklaracji prowadzi do niszczenia podmiotowości człowieka i narodu, faktycznie czyniąc z nich przedmioty. Otwarcie upomina się o poszanowanie fundamentalnych praw człowieka, prawa do wolności religijnej, swobodnego zrzeszania się i tworzenia związków zawodowych. Łamanie tych praw stanowi również jedną z form ubóstwa występującego w świecie (por. SRS 15).

Papież wyraża przekonanie, że w powszechnym odczuciu każdy ze wspomnianych wyżej bloków politycznych ma charakterystyczną dla siebie skłonność do imperializmu lub jakiejś formy neokolonializmu. Dwubiegunowy

12 Por. G. Weigel, Świadek nadziei. Biografia papieża Jana Pawła II, dz. cyt., s. 706-708. 
podział świata (Wschód-Zachód) jest bezpośrednią przeszkodą w usunięciu zacofania w krajach rozwijających się lub mniej rozwiniętych. Polityczny, ideologiczny i militarny podział znacznie osłabia dążenie do solidarnej współpracy między narodami dla wspólnego dobra ludzkości, pokoju, rozwoju i sprawiedliwości. Na surową ocenę moralną zasługuje praktyka swobodnego handlu bronią przekraczającego niekiedy granice między blokami oraz fakt potężnego nagromadzenia broni nuklearnej, zdolnej do spowodowania totalnej zagłady (por. SRS 23).

Z powodu braku równowagi w świecie i występujących w nim konfliktów można odnotować istnienie milionów uchodźców, którzy na skutek wojen, prześladowań, klęsk żywiołowych zostali pozbawieni swoich ojczyzn, rodzin i domów. Inną bolesną plagą współczesności jest terroryzm, który prowadzi do zabijania i zastraszania niewinnych ludzi, przetrzymywania zakładników, niszczenia mienia i wywoływania klimatu strachu w imię ideologii budowania lepszego świata. Papież przypomina, że akty terroryzmu nie znajdują nigdy żadnego usprawiedliwienia, zaś chrześcijaństwo absolutnie zabrania „uciekania się do nienawiści, mordowania bezbronnych, do metody terroryzmu" (SRS 24).

Czynnikiem utrudniającym rozwój narodów jest problem demograficzny, wyrażający się w malejącym przyroście naturalnym w krajach bogatych i dużym wzroście urodzin w krajach słabo rozwiniętych. Za szczególnie niepokojące uznał papież kampanie przeciw przyrostowi naturalnemu, organizowane często wbrew tożsamości kulturowej i religijnej niektórych narodów oraz wbrew naturze samego rozwoju. Według niesprawdzonych teorii lansowanych w ubogich krajach przyrost naturalny jest ukazywany jako jedna z głównych przeszkód w rozwoju gospodarczym. Szerzona jest tam propaganda antynatalistyczna oraz nakazana niekiedy przez władze państwowe reglamentacja urodzeń. Działania te skierowane przeciwko wolności kobiet i mężczyzn są często wymuszane i opłacane przez zagraniczne ośrodki oraz traktowane jako konieczny czynnik warunkujący otrzymanie pomocy finansowej lub medycznej ${ }^{13}$.

Analiza zjawisk współczesnego świata dokonana przez papieża zawiera również pozytywne aspekty. Ojciec święty dostrzega u wielu ludzi mocną

13 Por. C. Strzeszewski, Katolicka nauka społeczna, dz. cyt., s. 337. 
świadomość własnej godności, troskę o poszanowanie praw człowieka oraz wzrost liczby różnorodnych stowarzyszeń. Doniosłą rolę odegrała bez wątpienia Deklaracja Praw Człowieka ogłoszona przez ONZ. Na pozytywną ocenę zasługują rozwój świadomości ekologicznej, narodowej oraz wzrastające przekonanie o potrzebie solidarności. Należy ponadto docenić zjawisko wzrostu poczucia wartości życia, międzynarodowej współzależności oraz konieczności współpracy na polu gospodarczym, naukowym i kulturowym.

\subsection{Autentyczny rozwój ludzki}

Przegląd współczesnych problemów świata stanowi konieczne tło do ukazania prawdziwego i pełnego rozwoju ludzkiego. Papież stanowczo odrzuca oświeceniowy pogląd, że rozwój jest procesem automatycznym, nieograniczonym, kumulatywnym i przebiegającym po prostych liniach. Nie może on zostać ograniczony wyłącznie do wymiaru ekonomicznego polegającego na samym gromadzeniu dóbr i usług. Pojęcie rozwoju należy rozważać w odniesieniu do człowieka ujmowanego integralnie. Rozwój mierzy się według ,powołania człowieka rozumianego całościowo, czyli według jego parametru wewnętrznego" (SRS 29). Jan Paweł II sytuuje ów wewnętrzny parametr w naturze człowieka stworzonego przez Boga. Chociaż encyklika wprost nie wyjaśnia tego pojęcia, to jednak z dalszego kontekstu można wnioskować, że wewnętrzny parametr oznacza sumienie człowieka, dzięki któremu poznaje on właściwą hierarchię wartości ${ }^{14}$.

Autor encykliki zauważa, że oprócz niedorozwoju istnieje w krajach wysoko uprzemysłowionych niepokojące zjawisko „nadrozwoju”, połączone z kreowaniem sztucznych potrzeb przez producentów i twórców reklam oraz propagowaniem „cywilizacji spożycia”, zwanej konsumizmem. Prowadzi ono do skażenia środowiska, do pojawienia się chorób cywilizacyjnych, konfliktów ekonomicznych i ekologicznych. Niszczy rodzinę, rodząc mentalność przeciwną poczęciu nowego życia oraz generując postawy skrajnie hedonistyczne i egoistyczne. Błędna koncepcja rozwoju, oparta jedynie na kategorii „mieć”, prowadzi do niewolniczego poddania się konsumpcji połączonej

14 Por. A. Dylus, Nauka solidarnego rozwoju, [w:] Przewodnik po encyklikach. Myślac z Janem Pawłem II (komentarze M. Zięba, rozmawiał P. Kozacki) Poznań 2003, s. 145. 
z równoczesnym poczuciem radykalnego nienasycenia. W rezultacie zmierza ona nieuchronnie do praktycznego materializmu, który zagłusza najgłębsze pragnienia ludzkiego serca. Posiadanie rzeczy samo przez się nie jest zdolne do doskonalenia podmiotu ludzkiego. Papież podkreśla istotną różnicę między „mieć” i „być”, ale zaznacza przy tym, że „mieć” nie musi koniecznie przeciwstawiać się „być”. Posiadanie rzeczy nie jest złe samo w sobie. Staje się moralnie złe wówczas, gdy nie uwzględnia ,jakości i hierarchii dóbr" (SRS 28). Celem posiadania rzeczy jest pomoc w urzeczywistnianiu ludzkiego powołania, w rozwijaniu wartości humanistycznych i duchowych ${ }^{15}$.

W świetle Pisma Świętego obecny rozwój człowieka jest etapem historii zapoczątkowanej w dziele stworzenia. Niestety rozwój ten jest wciąż zagrożony poprzez nieposłuszeństwo człowieka wobec woli Stwórcy i pokusę materializmu. Ewangeliczna przypowieść o talentach (Mt 25, 14-30) przypomina, że człowiek jest odpowiedzialny za dzieło stworzenia. Wiara w Chrystusa jako Odkupiciela rzuca jeszcze pełniejsze światło na rozumienie integralnego rozwoju, który wpisuje się w odwieczny plan Boży. Dzięki odkupieniu dokonanemu przez Chrystusa cała historia świata, naznaczona zarówno porażkami, jak i sukcesami, zmierza do osiągnięcia swej pełni w Bogu (por. SRS 31). Ludzkie marzenia o nieograniczonym postępie zostają gruntownie przemienione i włączone w rzeczywistość zmartwychwstania Chrystusa. Stają się one możliwe do spełnienia tylko dzięki temu, że Bóg od początku postanowił uczynić człowieka uczestnikiem swej chwały (por. Ef 1, 3-4).

Wiara stanowi dla chrześcijan ważny impuls do zajmowania się kwestą integralnego rozwoju. Papież przypomina nauczanie ojców Kościoła (św. Bazylego Wielkiego, św. Augustyna), którzy rozwijają optymistyczną wizję dziejów i ludzkiej pracy, dostrzegając wieczną wartość szlachetnych ludzkich dokonań odkupionych przez Chrystusa i skierowanych ku Królestwu Bożemu (por. SRS 31). Wzywa do integralnego rozwoju, który oprócz aspektów ekonomicznych i społecznych będzie uwzględniał tożsamość kulturową różnych narodów i otwartość człowieka na Transcendencję. Właściwe rozumienie rozwoju wymaga respektowania praw ludzkich, zarówno osobistych, jak i społecznych,

15 Por. J. Mariański, Kościół a współczesne problemy społeczno-moralne. Kwestie wybrane, Lublin 1992, s. $120-122$. 
łącznie z prawami ludów i narodów ${ }^{16}$. Istnieje wewnętrzny związek między autentycznym rozwojem a poszanowaniem praw człowieka. Oprócz aspektu ekonomicznego rozwój ma istotny wymiar moralny i duchowy (por. SRS 33). Pomijanie ich prowadzi człowieka do stanu głębokiego niezadowolenia i ostatecznie jest czymś niemożliwym do zaakceptowania.

Pełny rozwój musi urzeczywistniać się w ramach solidarności i wolności, z respektowaniem porządku prawdy i dobra, który jest właściwy każdemu człowiekowi. Dodatkowo chrześcijanin swoje zaangażowanie w rozwój wiąże z poszanowaniem niepowtarzalnej godności obrazu Bożego obecnego w człowieku powołanym do pełnego uczestnictwa w prawdzie i dobru. Prawdziwy rozwój musi się opierać na miłości Boga i bliźniego, dzięki czemu przyczynia się do polepszenia stosunków między jednostkami i społeczeństwem. Moralny wymiar rozwoju wiąże się z odpowiedzialnym wykorzystywaniem dóbr naturalnych. Powinien uwzględniać zasadę, że człowiek nie posiada absolutnej władzy nad światem stworzonym, lecz sam będąc poddany prawom moralnym, nie może ich dowolnie przekraczaćc ${ }^{17}$.

\section{Solidarność a pokój}

Podstawowym warunkiem niezbędnym dla rozwoju człowieka i narodów jest zrozumienie znaczenia realnej współzależności między wszystkimi ludźmi i wszystkimi narodami. Jan Paweł II jest przekonany, że współzależność domaga się przezwyciężenia błędnej polityki bloków militarnych, ekonomicznych i politycznych oraz odrzucenia wszelkich form imperializmu. Ponadto niezwykle pilną sprawą staje się przekształcenie głębokiej nieufności występującej w społeczeństwach w harmonijną współpracę ${ }^{18}$.

Encyklika wskazuje, że poważną przyczyną hamującą integralny rozwój człowieka są struktury grzechu, wśród których na szczególną dezaprobatę zasługują wyłączna żądza zysku i pragnienie władzy za wszelka cenę. Rodzą

16 Por. F. J. Mazurek, Prawa człowieka w nauczaniu społecznym Kościoła, Lublin 1991, s. 163.

17 Por. Papieska Rada Iustitia et Pax, Kompendiumnauki społecznej Kościoła, tłum. D. Chodyniecki, red. K. Ryczan, Kielce 2005, 102.

18 Por. J. Mazur, Katolicka nauka społeczna, dz. cyt., s. 154. 
się one jako owoc niedopuszczalnej absolutyzacji tych postaw ludzkich, które z założenia prowadzą do działań przeciwnych dobru człowieka ${ }^{19}$. Do pełnej i rzetelnej analizy sytuacji współczesnego świata nie wystarczą same pojęcia ekonomiczne, polityczne i gospodarcze, lecz potrzeba zastosować kategorie grzechu i struktur grzechu (por. SRS 36). Należy pamiętać, że grzechy osobiste prowadzą do stworzenia struktur, sytuacji, mechanizmów i systemów zła. Ich zniewalająca siła polega na tym, że wzmacniają i rozpowszechniają zło głównie poprzez uzależnienie człowieka od grzechu, blokując w ten sposób integralny rozwój indywidualnego człowieka i całych narodów ${ }^{20}$.

W odróżnieniu od reprezentantów latynoamerykańskiej teologii wyzwolenia ${ }^{21}$, akcentujących bezosobowość struktur zła, papież podkreśla, że $\mathrm{u}$ ich podstaw zawsze stoi określony grzech konkretnych ludzi. Struktury grzechu, chociaż często mocne i dobrze zorganizowane, nie są jednak niepokonalnymi determinizmami społecznymi. Człowiek nie jest na nie bezwzględnie skazany. Może się im skutecznie przeciwstawić w ramach zorganizowanych działań wykluczających jednak przemoc i nienawiść jako środki przemian społecznych. Papież przypomina, że likwidacja samych struktur zła bez wewnętrznej odnowy moralnej człowieka szybko okaże się działaniem nieefektywnym. Proces przezwyciężenia zła społecznego potrzebuje w punkcie wyjścia gruntownego nawrócenia, prawdziwej przemiany postaw, szczerej rewizji sposobu odniesienia do siebie, do bliźnich, a nawet do „odległych wspólnot ludzkich”. Konieczna jest moralna przemiana sumień, umożliwiająca osiągnięcie takiego stopnia wrażliwości, że ludzie będą zdolni odczuwać niesprawiedliwość i łamanie praw człowieka w innych częściach świata jako coś, co dotyka również ich samych (por. SRS 37).

Najwłaściwszą odpowiedzią na świadomie przeżywaną współzależność między ludźmi i narodami jest solidarność, rozumiana jako cnota oraz postawa moralna i społeczna. Według papieża stanowi ona najpewniejszą drogę do pokoju, a przez to jednocześnie do osiągnięcia pełnego rozwoju. Ze względu na wieloznaczność tego terminu papież postanawia go precyzyjnie zdefinio-

\footnotetext{
19 Por. Papieska Rada Iustitia et Pax, Kompendium nauki społecznej Kościoła, 119.

20 Por. M. Zięba, „Jestem z wami”. Kompendium twórczości i nauczania Karola Wojtyły-Jana Pawła II, Kraków 2010, s. 90.

${ }^{21}$ Na temat podstawowych założeń teologii wyzwolenia zob. W. Piwowarski, ABC katolickiej nauki społecznej, cz. 1. Wprowadzenie, podstawy, kierunki, Pelplin 1993, s. 120-124.
} 
wać. Solidarność nie jest nieokreślonym współczuciem lub powierzchownym rozrzewnieniem nad złem dotykającym drugiego człowieka, lecz mocną wolą angażowania się na rzecz dobra wspólnego, czyli dobra wszystkich i każdego. W sferze społecznej jawi się jako skuteczny środek do zwalczania zła strukturalnego, które sprzeciwia się pokojowi i rozwojowi (por. SRS 39). Solidarność kieruje się logiką zaangażowania dla dobra bliźniego i służby zamiast wyzysku i panowania. Jej praktykowanie wymaga wrażliwości personalistycznej, polegającej na uznaniu innych ludzi za osoby, a nie za przedmioty lub środki służące jedynie do realizacji zamierzonych celów, które następnie można beztrosko wyrzucić. Solidarność wyraża się w odpowiedzialności za słabszych i w gotowości do dzielenia się dobrami z potrzebującymi. Jest obowiązkiem moralnym i wymaga zaangażowania społecznego ${ }^{22}$.

Według encykliki biedni i słabsi nie powinni jednak przyjmować biernej postawy, ale upominając się o swoje słuszne prawa, aktywnie włączać się w tworzenie dobra wspólnego. Prawdziwa solidarność wymaga eliminacji egoistycznych interesów, dopuszczenia słabszych do uczestnictwa w „uczcie życia" rozumianego jako możliwość korzystania z dóbr udzielonych przez Stwórcę wszystkim ludziom i narodom (por. SRS 39). W świetle wiary postawa ludzkiej solidarności nabiera dodatkowo specyficznie chrześcijańskich wymiarów, wyrażających się w całkowitej bezinteresowności, przebaczeniu i pojednaniu. Bliźni jest traktowany nie tylko jako osoba ludzka będąca podmiotem przysługujących mu praw, ale także jako żywy obraz Trójcy Świętej, stworzony przez Ojca, odkupiony przez krew Chrystusa i uświęcany przez Ducha. Winien on być kochany, nawet jeśli jest naszym wrogiem. Solidarność, której wymownymi świadkami są współcześni święci Kościoła (m.in. św. Piotr Klawer, św. Maksymilian Kolbe), wiąże się ściśle z miłością i dlatego słusznie może być nazwana znakiem rozpoznawczym uczniów Chrystusa. W obliczu realnego niebezpieczeństwa wojny, mającego swe źródło w polityce przeciwstawnych bloków politycznych oraz w ich militarnym i ekonomicznym imperializmie, postawa solidarności wydaje się pełnym nadziei sposobem na zachowanie i utrwalanie światowego po-

22 Por. Papieska Rada Iustitia et Pax, Kompendium nauki społecznej Kościoła, 119; J. Gocko, Od „Sollicitudo rei socialis” do „Caritas in veritate”. Solidarność kluczem do kwestii społecznej?, „Roczniki Teologii Moralnej” 4 (2012) 59, s. 32-37. 
koju (por. SRS 40). Kościół jako wspólnota wiary jest wezwany, aby zawsze stając po stronie słabych i ubogich, wspierać wszelkie wysiłki zmierzające do przekształcenia wzajemnej nieufności we współpracę. Dzięki temu stanie się dla świata promotorem zasady, że pokój jest dziełem solidarności (Opus solidaritatis pax) ${ }^{23}$.

\section{Sugestie duszpasterskie}

Na kanwie lektury papieskiej encykliki Sollicitudo rei socialis można sformułować kilka ważnych postulatów dla duszpasterskiej działalności w naszych parafiach.

Z pewnością w ramach katechezy dorosłych warto zwrócić uwagę na dynamiczne zmiany społeczne, polityczne, kulturowe i religijne zachodzące obecnie w Polsce i na świecie. Dzięki organizowanym prelekcjom z udziałem specjalistów z zakresu katolickiej nauki społecznej wierni będą mogli lepiej zapoznać się z panoramą współczesnych problemów, dokonać rzetelnej oceny rzeczywistości, dostrzec zarówno negatywne zjawiska występujące w życiu społecznym, jak i pozytywne aspekty rzeczywistości. Nabycie umiejętności odpowiedzialnego posługiwania się właściwymi narzędziami w opisie trudnych i złożonych problemów obecnych we współczesnym świecie stanowi ważne zadanie dla duszpasterskiej praktyki. Proponowane spotkania, prelekcje i dyskusje pomogą wiernym i duchownym w upowszechnianiu nauki społecznej Kościoła, która - zgodnie z encykliką - wchodzi w zakres jego ewangelizacyjnej misji.

W programie chrześcijańskiego wychowania dzieci i młodzieży nie powinno zabraknąć miejsca na refleksję nad znaczeniem integralnego rozwoju zarówno pojedynczych osób, jak i całych narodów. W konfrontacji z wadliwym rozumieniem rozwoju człowieka, ograniczonym jedynie do wymiaru ekonomicznego, trzeba podkreślać jego duchowy, moralny i kulturowy aspekt. Przypomniane przez Jana Pawła II podstawowe rozróżnienie między „mieć” i „być” z powodzeniem może być wykorzystane w materiałach for-

${ }^{23}$ Dla Piusa XII dewizą pontyfikatu było „pokój dziełem sprawiedliwości”, dla Pawła VI „pokój dziełem rozwoju”, dla Jana Pawła II „pokój dziełem solidarności”. Wszystkie te stwierdzenia należy ujmować łącznie. 
macyjnych poświęconych kwestiom prawdziwego i pełnego rozwoju człowieka oraz niebezpiecznemu zjawisku kultu posiadania. Człowiek potrzebuje „mieć”, aby bardziej „być”. Lansowanie wizji rozwoju opartego jedynie na gromadzeniu dóbr materialnych prowadzi do zubożenia naszego człowieczeństwa, które w konsekwencji zamyka drogę realizacji ludzkiego powołania i burzy właściwą hierarchię wartości.

Duszpasterstwo parafialne powinno wspierać, budować i wzmacniać podmiotowość człowieka poprzez tworzenie aktywnych wspólnot zrzeszających wiernych, którzy potrafią dostrzegać problemy społeczne w perspektywie zarówno lokalnej, jak i globalnej. Na szczególną uwagę zasługuje propozycja rozwijania preferencyjnej opcji na rzecz ubogich, rozumianej jako praktykowanie ofiarnej miłości w stosunku do głodujących, bezdomnych, pozbawionych pomocy lekarskiej i migrantów.

Encyklika Sollicitudo rei socialis stanowi zachętę dla parafialnych zespołów Caritas do pobudzania inicjatywy u ludzi doświadczonych ubóstwem i bezrobociem oraz wydobywania ich ze stanu społecznej marginalizacji. Organizowanie biur aktywizacji bezrobotnych, szkoleń i innych form podnoszenia kwalifikacji oraz świadczenie usług dla niepełnosprawnych poszukujących pracy stanowi pomoc w rozwijaniu poczucia własnej godności, w odkrywaniu swoich zdolności oraz budzeniu uzasadnionej nadziei na pozytywną zmianę swojej sytuacji.

Ważnym zadaniem duszpasterskim wynikającym z treści papieskiego dokumentu jest uświadomienie ludziom istnienia grzechu strukturalnego, który tylko pozornie nie ma sprawców. Trzeba zdecydowanie przypominać, że za niesprawiedliwymi strukturami społecznymi, politycznymi i gospodarczymi stoją konkretne negatywne postawy i motywacje ludzi, takie jak egoizm, kult pieniądza, techniki, ideologii, rasy lub klasy. W ramach sakramentu pokuty i kierownictwa duchowego warto pobudzać ludzi do odwagi w demaskowaniu konkretnych struktur grzechu (zorganizowanego wyzysku pracowników, korupcji, bezwzględnej żądzy zysku, programowego upokarzania ludzi, zmuszania do oszustw podatkowych itp.) i motywować do zbiorowego działania zmierzającego do usunięcia wynaturzonych mechanizmów siłą społecznej solidarności.

Niewątpliwie z kart encykliki płynie wezwanie do ponownego odkrycia i dowartościowania prorockiej funkcji Kościoła, który będąc w świecie sakra- 
mentem zmartwychwstałego Chrystusa, jest powołany do odważnego ukazywania zła i niesprawiedliwości społecznej. Należy przy tym pamiętać, że pełne radości i nadziei głoszenie prawdy ewangelicznej jest ważniejsze niż sama prezentacja negatywnych zjawisk, która w oderwaniu od wiary w przemieniającą moc słowa Bożego mogłaby prowadzić do pesymistycznych i katastroficznych wizji świata i historii. W ramach homilii, kazań i nauk rekolekcyjnych nie powinno zabraknąć pogłębionej refleksji nad właściwym rozumieniem wyzwolenia, które jest szlachetnym i wartościowym pragnieniem człowieka i społeczeństwa. Trzeba jasno wykazać, że wyzwolenie od wszelkich form zniewolenia moralnego, ekonomicznego i politycznego oraz pełny rozwój człowieka są ze sobą wewnętrznie powiązane i nie stanowią rzeczywistości wykluczających się. Wolność wyrastająca z daru Chrystusowego odkupienia stanowi jednocześnie zobowiązanie do postawy ofiarnej i solidarnej służby względem każdego człowieka. Uczestnictwo w procesie wyzwolenia człowieka z niewoli grzechu i wszelkich struktur zła jest obowiązkiem moralnym wszystkich członków Kościoła. Zadaniem wspólnoty parafialnej jest głoszenie chrześcijańskiego optymizmu, który wyrasta z wiary w możliwość prawdziwego wyzwolenia. Mimo negatywnych zjawisk i wielu smutnych doświadczeń Kościół powinien wciąż pokładać ufność w człowieku, który będąc obrazem Stwórcy, wciąż jest zdolny do czynienia dobra. Budowanie chrześcijańskiej kultury nadziei stanowi istotne wyzwanie w kontekście niebezpieczeństwa rozpaczy, pesymizmu i bierności.

W treści omawianej encykliki znajdujemy zaproszenie do ponownego odkrycia społecznego wymiaru Eucharystii, która będąc ofiarą Chrystusa, stanowi jednocześnie uobecnienie Królestwa Bożego w naszej ziemskiej historii i zapowiedź jego ostatecznego nadejścia. Z tej racji należy pogłębiać u wiernych świadomość, że Eucharystia ze swej natury jest sakramentem społecznym, w którym Chrystus jednoczy nas i posyła, abyśmy poprzez działania na rzecz rozwoju i pokoju czynili świat bardziej ludzkim i w ten sposób przygotowywali Jego powtórne przyjście. Kształtowanie postawy ludzkiego zaangażowania w pozytywną przemianę świata we współpracy z łaską Bożą mieści się z pewnością w katalogu aktualnych wyzwań duszpasterskich. 


\section{Summary}

\section{Pastoral implications of pope John Paul II's encyclical Sollicitudo rei socialis}

The canonization of Pope John Paul II constitutes a really great opportunity to rediscover the value of papal social thought. In this article, the author deals with the question of pastoral implications in the encyclical Sollicitudo rei socialis issued in 1987. The first part discusses the origins and socio - political context of the papal document. The second part presents the main ideas contained in the encyclical. The author analyses the range of problems present in the modern world, shows the integral understanding of human development and indicates the relationship between solidarity and peace. In the third and final part of the article, the author emphasizes the relevance of various aspects of the message contained in the encyclical and formulates particular indications for pastoral work. He draws attention to the necessity to enhance the social aspect of the Eucharist and the need to instil in believers attitudes of solidarity and responsibility for full human development, both on the individual and community level.

Keywords: Pope John Paul II, encyclical Sollicitudo rei socialis, integral human development, peace, solidarity, freedom, pastoral work

\section{Pastoralne implikacje encykliki Jana Pawła II Sollicitudo rei socialis}

Kanonizacja Jana Pawła II stanowi bardzo dobrą okazję do ponownego odkrycia wartości społecznej myśli papieża. W niniejszym artykule autor podejmuje kwestię duszpasterskich implikacji encykliki Sollicitudo rei socialis wydanej w 1987 roku. W pierwszej części omawia genezę i społeczno-polityczny kontekst papieskiego dokumentu. W drugiej części prezentuje najważniejsze idee zawarte w encyklice. Analizuje panoramę problemów współczesnego świata, przedstawia integralne rozumienie rozwoju człowieka oraz wskazuje na relacje między solidarnością i pokojem. W trzeciej i zarazem ostatniej części artykułu autor podkreśla aktualność wielu aspektów przesłania zawartego w encyklice oraz formułuje konkretne wskazania dla duszpasterstwa parafialnego. Zwraca uwagę na konieczność dowartościowania społecznego aspektu Eucharystii oraz na potrzebę kształtowania u wierzących postawy solidarności i odpowiedzialności za pełny rozwój człowieka zarówno w wymiarze indywidualnym, jak i wspólnotowym.

Słowa kluczowe: Jan Paweł II, encyklika Sollicitudo rei socialis, integralny rozwój człowieka, pokój, solidarność, wolność, duszpasterstwo 


\section{Bibliografia}

Buttiglione R., Myśl Karola Wojtyły, tłum. J. Merecki, Lublin 2010.

Dylus A., Nauka solidarnego rozwoju, [w:] Przewodnik po encyklikach. Myśląc z Janem Pawłem II (komentarze M. Zięba, rozmawiał P. Kozacki), Poznań 2003, s. 137-155.

Gocko J., Od „Sollicitudo rei socialis” do „Caritas in veritate”. Solidarność kluczem do kwestii społecznej?, „Roczniki Teologii Moralnej” 4 (2012) 59, s. 31-43.

Klose A., Katolicka nauka społeczna w zarysie, tłum. Z. Kowalska, Tarnów 1995.

Majka J., Nauka społeczna Kościoła, jej charakter i miejsce w orędziu ewangelicznym, [w:] Dokumenty nauki społecznej Kościoła, cz. 1, red. M. Radwan, L. Dyczewski, wyd. II zmienione, Lublin 1996, s. 11-58.

MariańskiJ., Kościół a wspótczesne problemy społeczno-moralne. Kwestie wybrane, Lublin 1992.

Mazur J., Katolicka nauka społeczna, Kraków 1992.

Mazurek F. J., Prawa człowieka w nauczaniu społecznym Kościoła, Lublin 1991.

Papieska Rada Iustitia et Pax, Kompendium nauki społecznej Kościoła, tłum. D. Chodyniecki, red. K. Ryczan, Kielce 2005.

Piwowarski W., ABC katolickiej nauki społecznej, cz. 1. Wprowadzenie, podstawy, kierunki, Pelplin 1993.

Pyszka S., Krótko o społecznej nauce Kościoła, Kraków 2003.

Strzeszewski C., Katolicka nauka społeczna, Lublin 1994.

Weigel G., Świadek nadziei. Biografia papieża Jana Pawła II, tłum. M. Tarnowska i in., Kraków 2009.

Zięba M.,Jestem z wami. Kompendium twórczości i nauczania Karola Wojtyły - Jana Pawła II, Kraków 2010. 